Tersedia online di: http://ejournal-balitbang.kkp.go.id/index.php/jra

\title{
KERAGAMAN GENETIK TIGA GENERASI IKAN TAMBAKAN (Helostoma temminkii) DALAM PROGRAM DOMESTIKASI
}

\author{
Otong Zenal Arifin\#, Wahyulia Cahyanti, dan Anang Hari Kristanto \\ Balai Riset Perikanan Budidaya Air Tawar dan Penyuluhan Perikanan \\ (Naskah diterima: 19 Januari 2017; Revisi final: 2 Maret 2017; Disetujui publikasi: 20 Maret 2017)
}

\begin{abstract}
ABSTRAK
Suatu penelitian untuk melihat keragaman genetik tiga generasi ikan tambakan dalam program domestikasi telah dilakukan di Balai Riset Perikanan Budidaya Air Tawar dan Penyuluhan Perikanan, Bogor. Tujuan penelitian ini adalah untuk mengevaluasi keragaman genetik generasi tetua/awal (G0), generasi pertama (G1), dan generasi kedua (G2) dalam program domestikasi ikan tambakan. Pengujian keragaman genetik dilakukan dengan metode PCR-RAPD menggunakan tiga primer, yakni OPA-2, OPA-8, dan OPC-2. Hasil yang diperoleh menunjukkan adanya perbedaan jumlah (7-15) dan ukuran fragmen (200-2.800 bp) yang dihasilkan, dengan frekuensi kemunculan alel berkisar antara 0,00-1,00 dari 31 lokus. Enam fragmen dari OPC-2 (1.400 bp, $1.300 \mathrm{bp}, 1.100 \mathrm{bp}, 800 \mathrm{bp}, 600 \mathrm{bp}, 500 \mathrm{bp}$ ), lima fragmen dari OPA-2 (1.350 bp, 1.000 bp, $900 \mathrm{bp}, 800 \mathrm{bp}, 520 \mathrm{bp})$, dan dua fragmen dari OPA-8 (1.000 bp, $550 \mathrm{bp}$ ) merupakan fragmen marka spesifik ikan tambakan pada penelitian ini. Keragaman genetik ikan tambakan antar generasi tergolong rendah, dengan nilai persentase polimorfisme berkisar antara $6,45 \% 35,48 \%$ dan nilai heterozigositas berkisar antara 0,03-0,16. Terjadi penurunan polimorfisme dan heterozigositas dari generasi tetua/awal (G0) ke generasi pertama (G1) dan kembali naik pada generasi kedua (G2). Dalam program domestikasi, nilai efektif induk (Ne) sebaiknya lebih dari 100, dengan nilai laju inbreeding (F) tidak lebih dari 0,005.
\end{abstract}

\section{KATA KUNCl: keragaman genetik; PCR-RAPD; generasi; tambakan}

ABSTRACT: Genetic diversity of three generations of kissing gourami (Helostoma temminkii) under a domestication program. By: Otong Zenal Arifin, Wahyulia Cahyanti, and Anang Hari Kristanto

A study to examine the genetic diversity of three generations of kissing gourami under a domestication program has been conducted at the Research Institute for Freshwater Aquaculture and Fisheries Extension, Bogor. The purpose of this study was to evaluatethe genetic diver sity of the elder generation (G0), first generation (G1), and second generation (G2) of kissing gourami under the domestication program. The genetic diversity examination was conducted through a PCR-RAPD method using three primers, namely OPA-2, OPA-8, and OPC-2. The obtained results indicated a difference in the number (7-15) and size of the fragments (200-2.800 bp) with the frequency of allele occurrence ranged from 0.00 to 1.00 from 31 loci. Six fragments from OPC-2 (1,400 bp; 1,300 bp; 1,100 bp; 800 bp; 600 bp; 500 bp), five fragments from OPA-2 (1,350 bp; 1,000 bp; $900 \mathrm{bp} ; 800 \mathrm{bp} ; 520 \mathrm{bp})$, and two fragments from OPA-8 (1,000 bp; $550 \mathrm{bp}$ ) were considered as species-specific markers of kissing gourami. The genetic diversity among the generations of the kissing gourami was low, with the percentage of polymorphism ranged from $6.45 \%$ to $35.48 \%$ and the value of heter ozygosity ranged from 0.03 to 0.16 . There was a decrease in polymorphism and heterozygosity values from the elder generation (G0) to the first generation (G1) and increased again but on the second generation (G2). In addition, the effective breeding value ( $\mathrm{Ne}$ ) in a domestication program should be more than 100 , and the average of inbreeding value $(\mathrm{F})$ is less than 0.005 .

\section{KEYWORDS: genetic diversity; PCR-RAPD; generation; kissing gourami}

\section{PENDAHULUAN}

Ikan tambakan (Helostoma temminkii, Cuvier 1829) merupakan komoditas lokal perikanan air tawar yang

\footnotetext{
\# Korespondensi: Balai Riset Perikanan Budidaya Air Tawar dan Penyuluhan Perikanan. Jl. Sempur No. 1, Bogor 16154, Indonesia. Tel. + 622518313200

E-mail: zenalarifin@gmail.com
}

berpotensi menjadi komoditas unggulan, karena mempunyai kemampuan dalam menoleransi ketersediaan oksigen rendah dalam air, bersifat herbivora sehingga mampu menekan ketergantungan terhadap pakan komersial. Nugroho et al. (2012) mengemukakan bahwa ikan tambakan merupakan salah satu dari 16 jenis ikan lokal yang diminati oleh 
stakeholder sebagai ikan potensial budidaya di Pulau Kalimantan. Dewasa ini, populasi ikan tambakan mengalami penurunan akibat penangkapan berlebih oleh nelayan. Berdasarkan data KKP (2006) jumlah produksi budidaya kolam, karamba, maupun sawah ikan tambakan berfluktuasi dari tahun 1996-2005 dan cenderung menurun. Pada tahun 2004 jumlah produksi budidaya ikan tambakan adalah 8.137 ton dan menurun pada tahun 2005 menjadi sebesar 3.263 ton, sehingga produksi budidaya ikan tambakan kolam mengalami penurunan produksi sekitar 59,89\% Dalam rangka peningkatan populasi ikan tambakan baik di alam maupun di lingkungan budidaya, dilakukan program domestikasi di luar habitat aslinya.

Domestikasi adalah proses penyesuaian ikan terhadap habitat baru yang akan memengaruhi kebiasaan-kebiasaan ikan itu sendiri, seperti kebiasaan makan yang juga merupakan penyesuaian dari genetik. Salah satu tujuan dari domestikasi adalah untuk mencegah terjadi kepunahan terhadap spesies yang terancam keberadaan kelangsungan hidupnya (Nurudin, 2013). Salah satu kegiatan yang menunjang keberhasilan domestikasi adalah karakterisasi genotipe, yang berfungsi untuk menentukan strategi pemijahan induk tiap generasi agar tidak terjadi penurunan keragaman genetik. Efektif breeding number $(\mathrm{Ne})$ merupakan indikator peningkatan koefisien silang dalam (inbreeding) per generasi, jumlah random genetic drift, dan berkurangnya keragaman genetik pada suatu populasi. Ne digunakan untuk mengendalikan tekanan inbreeding dan genetic drift. Ne dipengaruhi oleh jumlah induk yang memijah/kawin, dan perbandingan induk jantan dan betina (Falconer, 1989).

Keragaman genetik merupakan ragam dalam satu spesies baik antara populasi yang terpisah secara geografik maupun antara individu dal am satu populasi. Keragaman genetik timbul karena setiap individu mempunyai bentuk-bentuk gen yang khas, dapat bertambah apabila keturunan menerima kombinasi gen dan kromosom dari induk dalam proses reproduksi melalui rekombinasi gen yang terjadi. Proses rekombinasi ini dapat meningkatkan potensi keragaman genetik dengan mengatur ulang alel secara acak sehingga timbul kombinasi yang berbeda-beda (Indrawan, 2007). Suryanto (2003) mengemukakan keragaman genetik dapat terjadi karena adanya perubahan nukleotida penyusun DNA, yang dapat memengaruhi fenotipe organisme atau memengaruhi fenotipe suatu individu terhadap lingkungan tertentu. Genotipe yang sama, dapat menghasilkan fenotipe berbeda karena perbedaan interaksi dengan faktor lingkungan. Secara umum keragaman genetik dari suatu populasi dapat terjadi karena adanya mutasi, rekombinasi, atau migrasi gen.
Program domestikasi ikan tambakan yang telah dilakukan dari generasi awal (G0) sampai generasi kedua (G2) perlu diuji tingkat keragaman genetiknya, melalui pengamatan DNA menggunakan penanda molekuler. Penanda molekuler telah banyak digunakan untuk mengidentifikasi suatu individu atau genotipe, derajat kekerabatan, dan variasi genetik suatu populasi (Sharma et al., 2008). Random amplified polymorphism DNA (RAPD) adalah teknik molekuler berbasis PCR-RAPD yang dapat digunakan untuk mendeteksi polimorfisme ruas nukleotida pada DNA dengan memanfaatkan primer tunggal yang memiliki urutan nukleotida acak. Metode RAPD memiliki beberapa keunggulan di antaranya mampu mendeteksi sekuen nukleotida hanya dengan satu primer, polimorfisme tinggi, dan dapat digunakan tanpa mengetahui latar belakang genom sebelumnya (Dunham, 2004). Penanda molekuler RAPD merupakan sekuen DNA polimorfik yang dipisahkan oleh gel elektroforesis PCR menggunakan satu primer oligonukleotida pendek secara acak.

Tujuan dari kegiatan ini adalah untuk menganalisis keragaman genetik generasi awal (G0), generasi pertama (G1), dan generasi kedua (G2) dalam program domestikasi ikan tambakan melalui penanda molekuler RAPD.

\section{BAHAN DAN METODE}

\section{Penyediaan Ikan Uji}

Ikan uji yang digunakan adalah tiga generasi (G0, G1, dan G2) ikan tambakan yang berasal dari populasi Jawa Barat dalam program domestikasi. Pembentukan populasi dilakukan di Instalasi Riset Plasma Nutfah Perikanan Air Tawar Cijeruk, Balai Riset Perikanan Budidaya Air Tawar dan Penyuluhan Perikanan, Bogor. Populasi G1 dilakukan dengan memijahkan secara berpasangan 15 ekor jantan dan 15 ekor betina induk ikan G0 (bobot 138,3 \pm 5,44 g) di dalam akuarium secara semibuatan. Larva dari masing-masing pemijahan digabungkan, dipelihara sampai ukuran benih dan menjadi induk G1. Pemeliharaan dilakukan selama tujuh bulan di dalam tiga buah kolam sekat berukuran $3 \mathrm{~m} \times 3,5 \mathrm{~m} \times 1 \mathrm{~m}$ dengan tinggi air $60 \mathrm{~cm}$. Pemberian pakan awal berbentuk tepung dengan kandungan protein $41 \%$ dilanjutkan dengan pelet terapung kandungan protein 39\% $41 \%$ dan lemak 5\% dosis pakan diberikan sebanyak $5 \%$ dari biomassa, dilanjutkan dengan pakan protein 31\%35\%dan lemak $3 \% 5 \%$ dosis pakan sebanyak $3 \%$ per hari dari biomassa dengan frekuensi pemberian tiga kali sehari. Pembentukan generasi dua (G2) dilakukan dengan cara pemijahan secara massal 50 ekor jantan dan 50 ekor betina induk $\mathrm{G} 1$ berukuran bobot 70,7 $\pm 18,45 \mathrm{~g}$. 
Larva dan benih yang diperoleh dipelihara dalam tiga buah kolam sekat berukuran $3 \mathrm{~m} \times$ 3,5 m x $1 \mathrm{~m}$ selama tujuh bulan di kolam pemeliharaan seperti pada pemeliharaan pembentukan G1.

\section{Amplifikasi PCR-RAPD}

Sebanyak 10 ekor dari masing-masing generasi, diambil secara acak. Ikan uji populasi G0 diambil pada saat ikan baru didatangkan dari alam dengan ukuran ikan berkisar antara 30-50 g/ekor. Populasi G1 dan G2 diambil pada umur tujuh bulan dengan bobot masingmasing populasi 20-30 g/ekor dan 20-25 g/ekor. Kegiatan dilakukan di Laboratorium Biologi M olekuler, BRPBATPP Bogor. DNA genom diekstraksi dari sirip dada ( $\pm 150 \mathrm{mg}$ ) menggunakan Genomic DNA Purification Kit (Fermentas). Primer yang digunakan dalam amplifikasi DNA adalah OPC-2, OPA-2, dan OPA-8 (Tabel 1) mengacu pada penelitian yang dilakukan Sundari et al. (2012). Komposisi reaksi PCR adalah: DNA $1 \mu \mathrm{L}$, primer $0,5 \mu \mathrm{L}$ konsentrasi $25 \mathrm{nmol}$ (pengenceran 20:80), mastermix PCR (KAPA Robust kk 5701; 0,2 nM dNTPS, 2 nM MgCl 2 dan stabilizer) $6,5 \mu \mathrm{L}$, akuades $2 \mu \mathrm{L}$, sehingga diperoleh volume total $10 \mu \mathrm{L}$. Selanjutnya tabung mikro dimasukkan ke dalam thermocycler menggunakan program amplifikasi, yaitu satu siklus denaturasi awal pada suhu $94^{\circ} \mathrm{C}$ selama dua menit, 34 siklus yang terdiri atas denaturasi pada suhu $94^{\circ} \mathrm{C}$ selama satu menit, annealing $36^{\circ} \mathrm{C}$ selama satu menit, dan elongasi $72^{\circ} \mathrm{C}$ selama dua menit. Elongasi akhir dilakukan pada suhu $72^{\circ} \mathrm{C}$ selama tujuh menit. Hasil PCR dilihat melalui elektroforesis dalam gel agarose $1,5 \%$

\section{Analisis Data}

Keragaman genetik dianalisis menggunakan program TFPGA (Tools for Population Genotipe Analysis) (Nei \& Tajima, 1981). Polimorfisme genetik diukur dengan rataan heterozigositas $(\mathrm{H})$, jumlah dan frekuensi alel yang dihitung untuk semua lokus. Untuk melihat perbedaan keragaman genetik $\left(\mathrm{F}_{\mathrm{ST}}\right)$ digunakan analisis statistik dengan menggunakan AMOVA (Analysis Molecular Variance) pada selang keprecayaan $5 \%$
Nilai jumlah efektif induk ( $\mathrm{Ne}$ ) dan nilai laju inbreeding (F) dihitung berdasarkan rumus Tave (1999):

$$
\begin{gathered}
\mathrm{Ne}=\frac{4(\text { Jumlah induk jantan })(\text { Jumlah induk betina })}{\text { Jumlah induk jantan }+ \text { jumlah induk betina }} \\
\mathrm{F}=\frac{1}{2 \mathrm{Ne}}
\end{gathered}
$$

\section{HASIL DAN BAHASAN}

Analisis PCR-RAPD antar generasi (G0, G1, dan G2) menggunakan tiga primer menghasilkan jumlah dan ukuran fragmen berbeda. Primer OPC-2 menghasilkan jumlah fragmen sebanyak 9-15, OPA-2 sebanyak 7-15, dan OPA-8 sebanyak 10-14, dengan total jumlah fragmen sebanyak 31 buah lokus. Fragmen yang dihasilkan berukuran antara 200-2.800 bp dengan frekuensi kemunculan alel berkisar antara 0,00-1,00; seperti tertera pada Gambar 1 dan Tabel 2.

Jumlah dan ukuran fragmen yang dihasilkan dalam penelitian menggunakan ikan tambakan ini hampir sama dengan yang diperoleh Putriana (2011) yang menguji keragaman genetik tiga populasi ikan tambakan yang berasal dari Jawa, Jambi, dan Kalimantan Selatan menggunakan metode RAPD dengan primer OPA-2, OPC-2, dan OPC-5 dengan mendapatkan jumlah fragmen sebanyak 13 sampai 24 dengan kisaran ukuran fragmen antara 100-2.000 bp. Pada penelitian yang dilakukan Simatupang (2012) memperoleh jumlah fragmen yang dihasilkan pada tiga populasi ikan sepat menggunakan tiga primer (OPA-2, OPC-2, dan OPC-5) dihasilkan fragmen sebanyak 20-30 dengan ukuran basa pada kisaran 12-2.000 bp. Nugroho et al. (2011) pada penelitian menggunakan ikan uji hasil persilangan antara gurami Bastar-Paris, Bastar-Blusafir, dan ParisBlusafir mengunakan primer OPA-4 dan OPA-7 menghasilkan jumlah total pita yang diamati sebanyak 48 buah dengan panjang mulai 300 bp hingga 2.000 bp. Jumlah ini jauh lebih tinggi dibandingkan hasil amplifikasi pada galur murninya yaitu strain ikan gurami Bastar, Paris, dan Blusafir dengan menggunakan

Tabel 1. Primer yang digunakan pada analisis genetik RAPD tiga generasi ikan tambakan

Table 1. Primers used in the RAPD genetic analysis of three generations of

\begin{tabular}{|c|c|c|c|}
\hline $\begin{array}{l}\text { Jenis primer } \\
\text { Primer code }\end{array}$ & $\begin{array}{c}\text { Urutan basa }\left(5^{\prime}-3^{\prime}\right) \\
\text { Sequence }\left(5^{\prime}-3^{\prime}\right)\end{array}$ & $\begin{array}{l}\text { Panjang nukleotida } \\
\text { Nucleotide length }\end{array}$ & $\begin{array}{l}\text { Persentase G + C } \\
\text { Percentage G + C }\end{array}$ \\
\hline OPA-2 & TGC CGA GCT G & 10-mer & 80 \\
\hline OPA-8 & GTG ACG TAG G & 10-mer & 60 \\
\hline OPC-2 & GTG AGG CGT C & 10-mer & 70 \\
\hline
\end{tabular}
kissing gouramy 


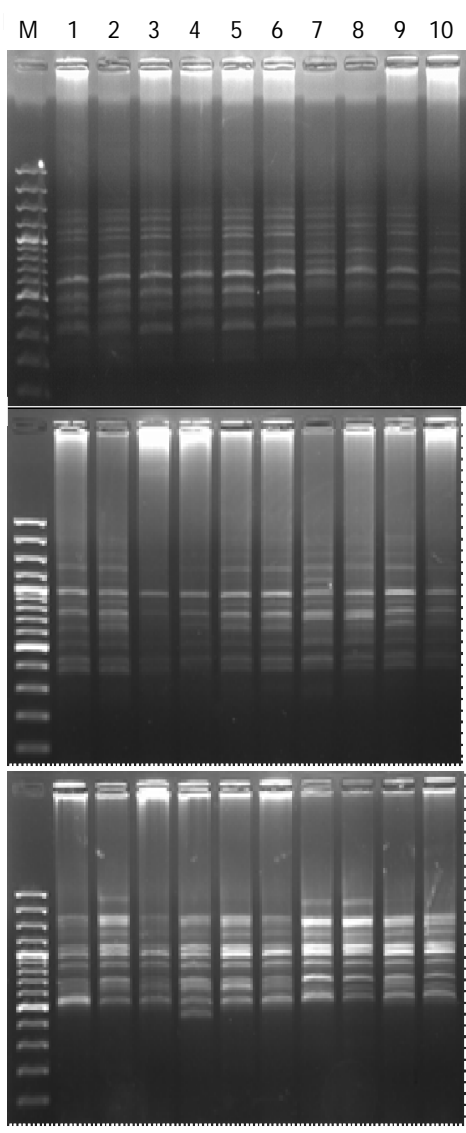

G0
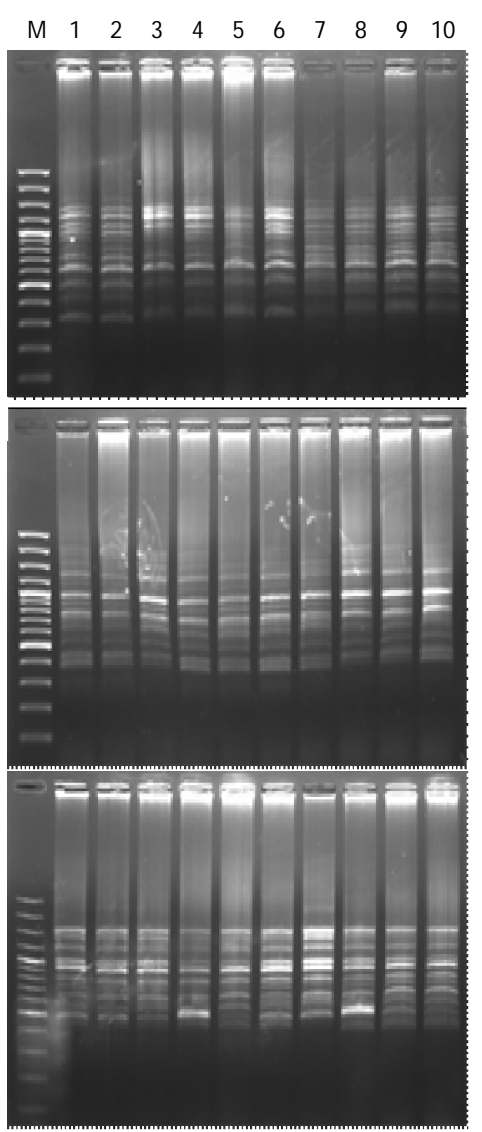

G1
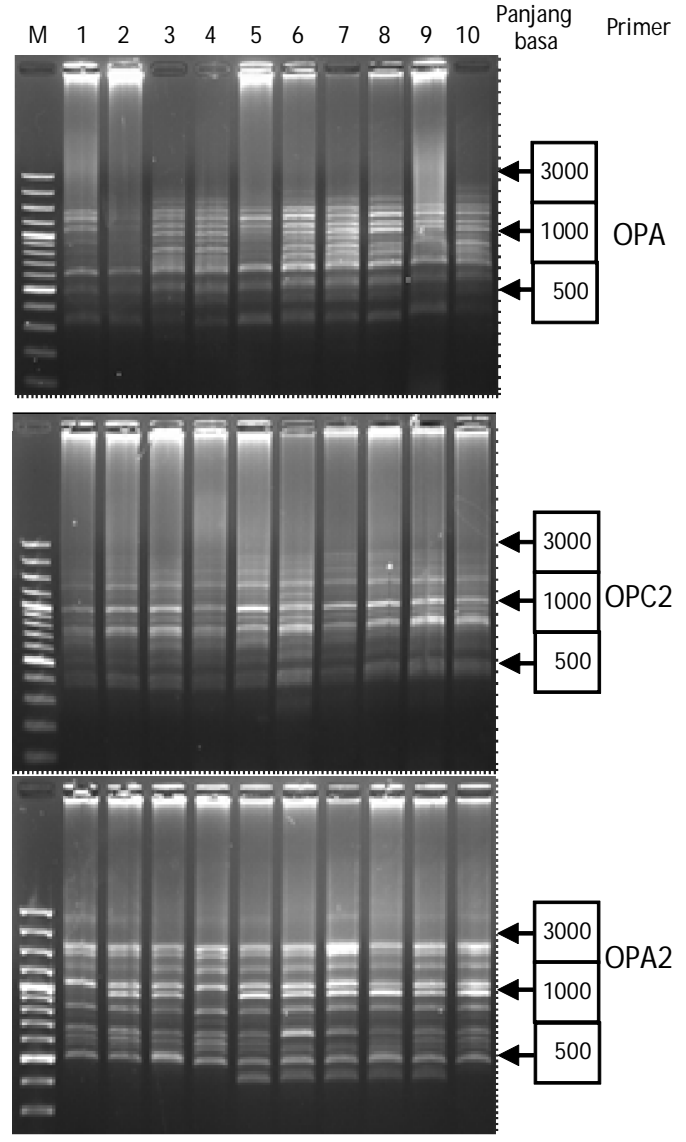

G2

Gambar 1. Hasil elektroforesis PCR-RAPD tiga generasi ikan tambakan (G0: generasi awal, G1: generasi pertama, G2: generasi kedua, M: marker DNA Gene Ruller 100 bp plus DNA Ladder dengan primer OPC-2, OPA-2, dan OPA-8, 1-10: sampel ikan).

Figure 1. Electrophoresis results of PCR-RAPD from three generations of kissing gourami (G0: the elder generations, G1: the first generation, G2: second generation, M: marker DNA Gene Ruller 100 bp plus DNA Ladder) with OPC-2, OPA-2, and OPA-8 primers, 1-10: fish sample).

primer yang sama yang menghasilkan sebanyak 28 buah pita (Nugroho, 2011). Pada penelitian lima strain ikan gurami Tambago, Palapah, Krista, Jepun, dan Merah, Nugroho et al. (2016) mendapatkan ukuran basa antara 300 hingga 2.000 bp. Hasil amplifikasi setiap primer memiliki karakter yang berbeda sehingga jumlah dan ukuran fragmen yang muncul pun berbeda. Penggunaan primer pada RAPD berpengaruh terhadap polimorfisme fragmen yang dihasilkan karena setiap primer memiliki situs penempelan sendiri sehingga fragmen dari DNA yang diamplifikasi oleh primer berbeda menghasilkan polimorfik dengan jumlah fragmen dan berat molekul berbeda (Roslim et al., 2004).

Berdasarkan ukurannya, enam fragmen pada OPC2 (1.400 bp, 1.300 bp, 1.100 bp, 800 bp, 600 bp, dan $500 \mathrm{bp}$ ), lima fragmen pada OPA-2 (1.350 bp, 1.000 bp, 900 bp, 800 bp, dan 520 bp), serta dua fragmen pada OPA-8 (1.000 bp dan 550 bp) merupakan fragmen yang selalu muncul pada semua individu ikan uji dan dapat dijadikan sebagai marka spesifik ikan tambakan pada penelitian ini. Parenrengi et al. (2012) mengemukakan tiga fragmen dari primer CA-01 (700 bp, $800 \mathrm{bp}$, dan $1.000 \mathrm{bp}$ ) dan empat fragmen (225 bp, 400 bp, 750 bp, dan 850 bp) dari primer P-40 merupakan fragmen yang selalu ada pada setiap individu dari tiga populasi ikan terbang (Hirundichthy oxycephalus) dapat dianggap sebagai marka spesifik spesies. Pada penelitian menggunakan tiga spesies ikan kerapu (Epinephelus aerolatus, E. merra, dan E. suillus), Parenrengi (2006) berhasil mendeterminasi lima fragmen (OPA02-950 bp, OPA08-950 bp, OPA16700 bp, OPA16-550 bp, OPA17-860 bp) dan terindikasi sebagai marka spesifik genus Epinephelus karena fragmen tersebut muncul pada tiga spesies ikan kerapu yang diuji. 


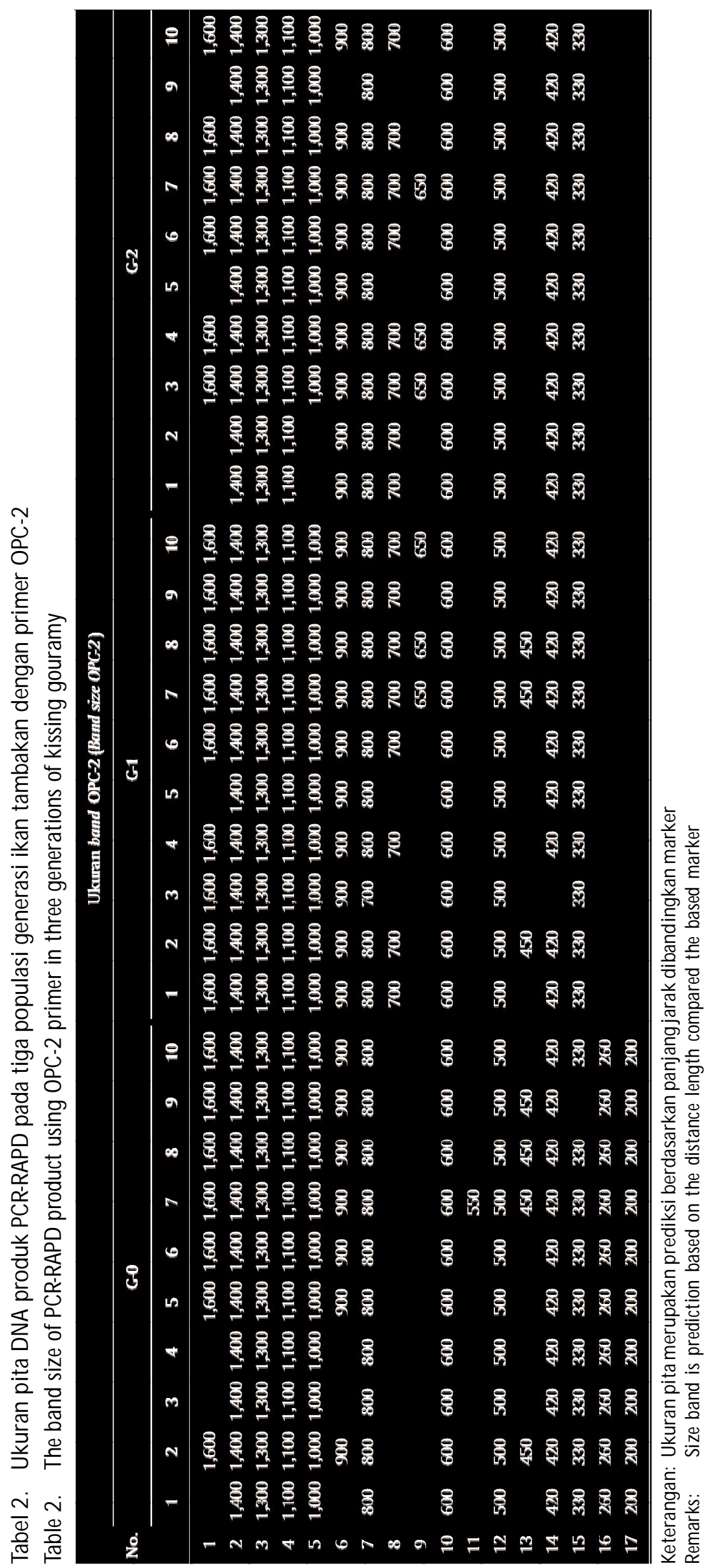


I

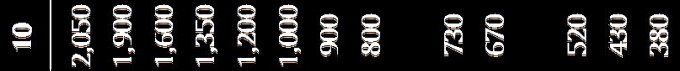

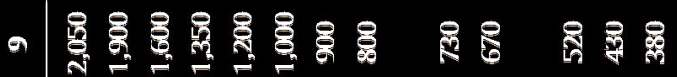

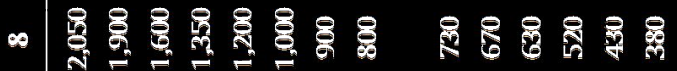

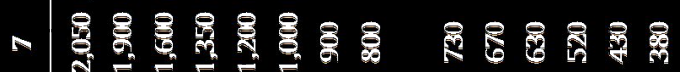

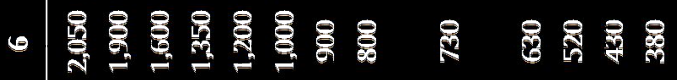

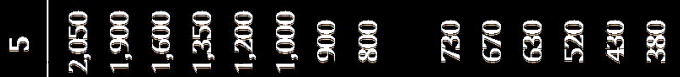

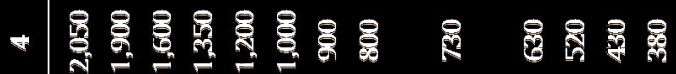

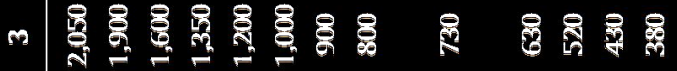

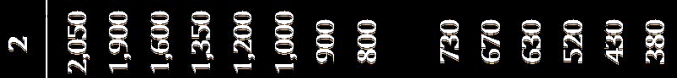

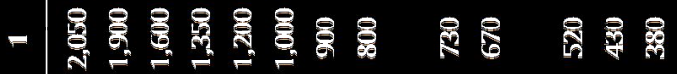

○ 曾

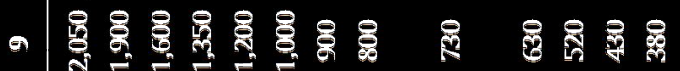

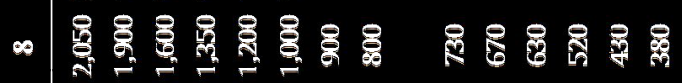

々 曾

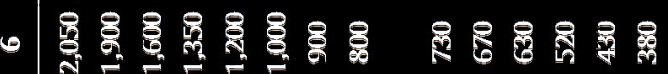

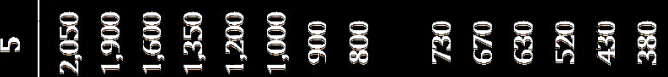

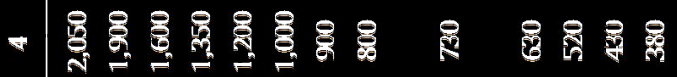

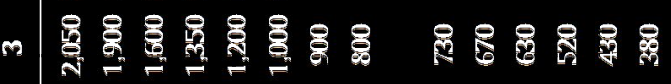

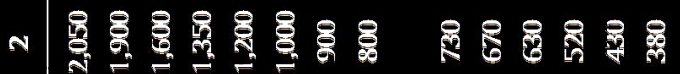

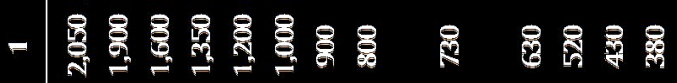

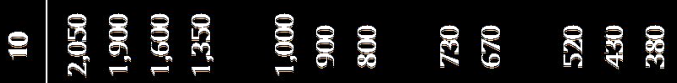

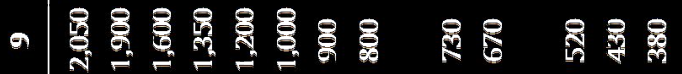

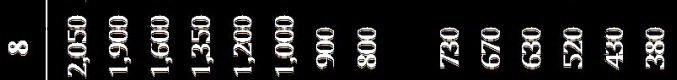

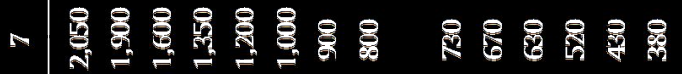

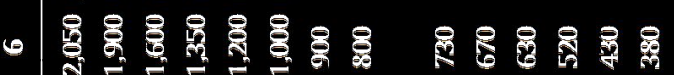

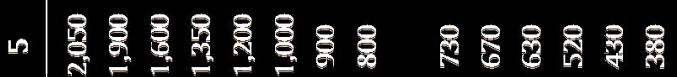

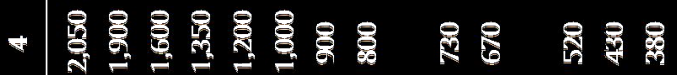

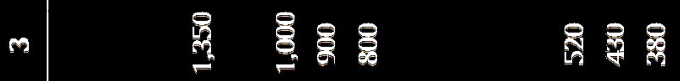

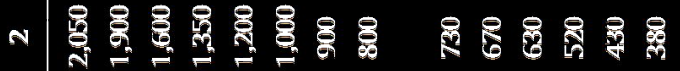

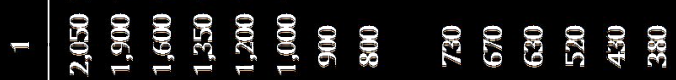

- N 


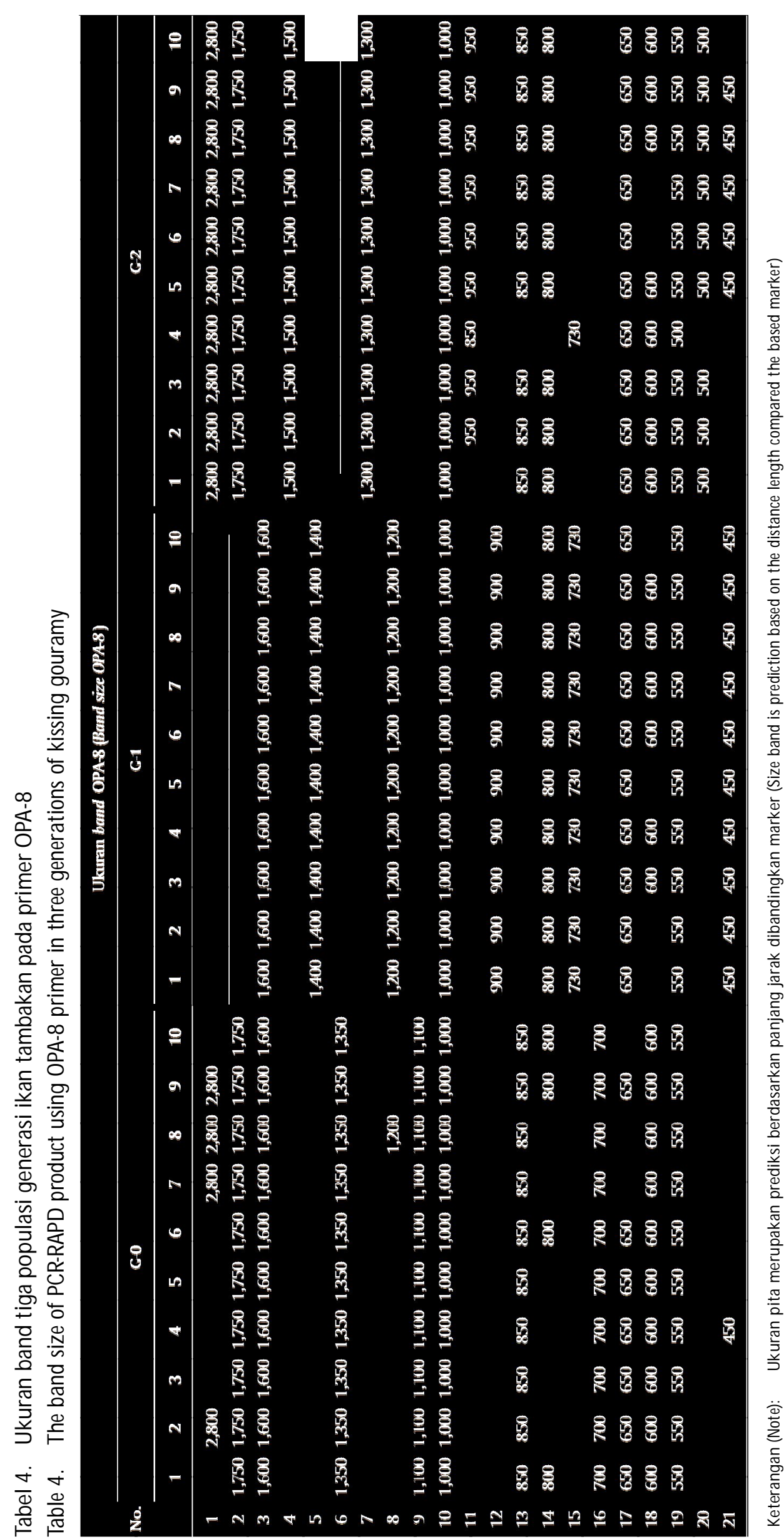


Keragaman genetik ditentukan dari ragam alel dalam lokus yang dihasilkan dari hasil elektroforesis. Keragaman genetik pada penelitian tiga generasi ikan tambakan yang dilakukan tergolong rendah, hal ini diperlihatkan dengan rendahnya persentase polimorfisme dari ketiga generasi ikan tambakan yang berkisar antara 6,45\%-35,48\% dengan nilai heterozigositas antara 0,03 sampai 0,16. Putriana (2011) yang melakukan analisis keragaman genetik tiga populasi ikan tambakan yang berasal dari Kalimantan Selatan, Jambi, dan Jawa Barat, yang menghasilkan persentase polimorfik yang tinggi, yaitu antara $57,14 \%$ sampai $60,71 \%$ dengan nilai heterozigositas antara 0,23 sampai 0,25 . Berdasarkan hasil analisis menunjukkan terjadi penurunan polimorfisme dan heterozigositas dari generasi induk awal (G0) ke generasi pertama (G1) dan kembali terjadi kenaikan pada generasi kedua (G2) (Tabel 5).

Penurunan nilai heterozigositas dan polimorfik dari G0 ke G1, diduga karena ikan tambakan yang digunakan dalam penelitian ini merupakan populasi dalam kegiatan domestikasi, sehingga sangat dimungkinkan terjadi penurunan keragaman genetik dari generasi ke generasi dikarenakan adanya inbreeding. Heterozigositas merupakan ukuran keragaman genetik berdasarkan proporsi jumlah individu heterozigot populasi. Penurunan tingkat keragaman genetik erat kaitannya dengan menurunnya heterozigositas gen. Hal ini dapat disebabkan karena adanya isolasi populasi, inbreeding, dan genetic drift
(So ewardi, 2007). Rendahnya keragaman genetik merupakan gambaran umum yang ditemui pada jenis ikan air tawar sebagai akibat keterbatasan migrasi secara alami (Nugroho et al., 2016). Tingginya keragaman genetik ikan yang dilakukan Putriana (2011) dikarenakan ikan tambakan yang dianalisis diduga karena ikan yang digunakan merupakan ikan yang berasal dari alam dengan wilayah yang berjauhan (Populasi Jawa, Sumatera, dan Kalimantan). Selain itu, dikemukakan pula bahwa ikan tambakan merupakan jenis ikan yang tidak merawat anaknya sehingga memungkinkan ikan tambakan untuk melakukan migrasi dengan jarak yang cukup jauh.

Peningkatan nilai heterozigositas dan polimorfik dari G1 ke G2 diduga jumlah induk yang digunakan pada pembentukan $\mathrm{G} 2$ lebih banyak dibandingkan pada pembentukan G1. Nilai rata-rata inbreeding suatu populasi ditentukan dari jumlah induk efektif $(\mathrm{Ne}=$ effective breeding number), jumlah efektif induk merupakan salah satu bagian paling penting dari informasi yang dapat diperoleh dari populasi dalam pembenihan. Jumlah induk efektif adalah salah satu konsep yang paling penting dalam manajemen induk, karena memberikan indikasi mengenai stabilitas genetik dari populasi, hal ini dikarenakan $\mathrm{Ne}$ berbanding terbalik dengan tekanan inbreeding dan genetic drift (Tave, 1999). Gjedrem \& Baranski (2009) yang melakukan kegiatan seleksi individu pada ikan mas (Cyprinus carpio) dan ikan nila (Oreochromis niloticus) dalam upaya peningkatan keragaan pertumbuhan

Tabel 5. Jumlah sample, jumlah fragmen, persentase polimorfisme, heterozigositas, dan ukuran fragmen tiga generasi ikan tambakan menggunakan PCR-RAPD dengan tiga primer berbeda

Table 5. Number of samples, total number of fragments, percentages of polymorphism, heterozygosity, and size ranges of fragment of three generations kissing gourami using three different primers of PCR-RAPD

\begin{tabular}{lccc}
\hline \multicolumn{1}{c}{$\begin{array}{c}\text { Parameter } \\
\text { Parameters }\end{array}$} & \multicolumn{3}{c}{ Populasi (Populations) } \\
\cline { 2 - 4 } & G-0 & G-1 & G-2 \\
\hline $\begin{array}{l}\text { Jumlah sampel (ekor) } \\
\text { Number of samples (ind.) }\end{array}$ & 10 & 10 & 10 \\
$\begin{array}{l}\text { Jumlah fragmen (lokus) } \\
\text { Total number of fragments (Loci) }\end{array}$ & $11-15$ & $10-15$ & $9-14$ \\
$\begin{array}{l}\text { Persentase polimorfisme } \\
\text { Percentage of polymorphism }\end{array}$ & 35.48 & 6.45 & 16.13 \\
$\begin{array}{l}\text { Heterozigositas } \\
\text { Heterozygosity }\end{array}$ & 0.16 & 0.03 & 0.08 \\
$\begin{array}{l}\text { Ukuran fragmen (bp) } \\
\text { Size range of fragments (bp) }\end{array}$ & $200-1,600$ & $380-2,050$ & $450-2,800$ \\
\hline
\end{tabular}


dilaporkan tidak efektif. Hal tersebut antara lain karena rendahnya keragaman genetik populasi dasar akibat sedikitnya jumlah Ne pasangan induk-induk pembentuknya.

Pada penelitian ikan sepat yang dilakukan Simatupang (2012), diperoleh persentase polimorfisme pada populasi sepat yang berasal dari Kalimantan dan Sumatra 26,67\%, lebih tinggi dibandingkan polimorfisme pada populasi sepat yang berasal dari Jawa yang mempunyai nilai sebesar 13,33\% Demikian juga heterozigositas populasi ikan sepat populasi Kalimantan $(0,12)$ dan Sumatera $(0,11)$, lebih tinggi dibandingkan heterozigositas populasi ikan sepat populasi Jawa $(0,06)$. Pada ikan semah (Tor sorro) nilai heterozigositas berkisar antara 0,09090,1407 (Asih et al., 2008), ikan kelabau (Osteochilus kelabau) berkisar antara 0,0100-0,1651 (Kusmini et al., 2011). Arifin et al. (2007) memperoleh nilai keragaman genetik yang tinggi pada empat populasi ikan nila dengan rata-rata nilai heterozigositas 0,2146 dan polimorfisme 56,62\% Dunham (2004) mengemukakan populasi dengan keragaman genetik yang tinggi memiliki peluang hidup yang lebih tinggi, karena banyak alternatif gen atau kombinasi gen yang tersedia untuk merespons perubahan kondisi lingkungan yang dihadapi. Gusmiaty et al. (2012) mengemukakan bahwa keberhasilan amplifikasi DNA genom menggunakan teknik RAPD sangat ditentukan oleh urutan basa primer yang digunakan, serta kualitasnya atau kandungan primer dalam setiap reaksi. Jumlah dan intensitas pita DNA yang dihasilkan setelah amplifikasi DNA dengan PCR sangat tergantung bagaimana primer mengenal urutan DNA komplementernya pada cetakan DNA (DNA template) yang digunakan (Tingey et al., 1994).

Berdasarkan nilai pada Tabel 6, menunjukkan tidak terdapat perbedaan genetik yang nyata antar generasi ikan tambakan yang diuji $(P>0,05)$. Hal ini dimungkinkan terjadi karena ikan yang diuji awalnya berasal dari satu populasi, yaitu populasi ikan tambakan yang awalnya (G0) berasal dari Jawa Barat, yang membedakan hanyalah generasi dari masingmasing populasi. Mulyasari et al. (2010) mengemukakan populasi yang tidak berbeda nyata mungkin disebabkan banyaknya kesamaan genetik antar populasi-populasi tersebut.

Penggunaan induk yang tidak sesuai kaidah genetika terbukti dapat menurunkan tingkat keragaman genetik ikan yang dihasilkan. Pada pembentukan generasi pertama jumlah induk yang digunakan adalah 15 pasang (15 ekor jantan dan 15 ekor betina) yang dilakukan secara berpasangan dengan nilai Ne sebesar 30 dan nilai laju inbreeding (F) sebesar 0,017; sedangkan pada pembentukan generasi kedua adalah sebanyak 50 pasang (50 ekor jantan dan 50 ekor betina) yang dilakukan secara massal dengan nilai Ne sebesar 100 dan nilai laju inbreeding (F) sebesar 0,005 . Oleh karena itu, dalam program domestikasi perlu untuk memperhatikan nilai jumlah efektif induk (Ne) yang dipergunakan dalam perkawinan agar dapat menekan nilai inbreeding dan genetic drift. Untuk menekan laju inbreeding agar tidak tinggi, nilai $F$ sebaiknya tidak lebih dari 0,005 dengan nilai Ne tidak kurang dari 100.

\section{KESIMPULAN}

Ukuran fragmen yang dihasilkan berkisar antara 200-2.800 bp dengan frekuensi kemunculan alel antara $0,001,00$ dan berjumlah 31 lokus. Enam fragmen dari OPC-2 (1.400 bp, 1.300 bp, 1.100 bp, 800 bp, 600 bp, $500 \mathrm{bp}$ ), lima fragmen dari OPA-2 (1.350 bp, $1.000 \mathrm{bp}$, 900 bp, 800 bp, 520 bp), dan dua fragmen dari OPA-8 (1.000 bp, $550 \mathrm{bp}$ ) merupakan fragmen marka spesifik ikan tambakan pada penelitian ini. Nilai polimorfisme dan heterozigositas $\mathrm{G} 0$ sebesar $35,48 \%$ dan 0,16 ; turun menjadi $6,45 \%$ dan 0,03 pada G1 dan naik menjadi

Tabel 6. Nilai Fst pada perbedaan keragaman genetik dari tiga generasi ikan tambakan

Table 6. Fst value on the different genetic diversity of three generations of kissing gouramy

\begin{tabular}{|c|c|c|c|}
\hline Populasi (Populations) & G-0 & G-1 & G-2 \\
\hline G-0 & 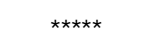 & & \\
\hline G-1 & $0.0011^{\mathrm{ns}}$ & watesk & \\
\hline G-2 & $0.0136^{\mathrm{ns}}$ & $0.0040^{\mathrm{ns}}$ & 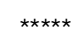 \\
\hline
\end{tabular}

Keterangan (Note): $\mathrm{ns}=$ tidak berbeda nyata $(\mathrm{P}>0,05)$ (ns $=$ not significantly different $(P>0.05))$ 
16,13\%dan 0,08 pada G2. Dalam program domestikasi, untuk menekan inbreeding sebaiknya nilai $F$ tidak lebih dari 0,005; dengan nilai efektif induk (Ne) lebih dari 100.

\section{UCAPAN TERIMA KASIH}

Ucapan terima kasih disampaikan kepada Sri Sundari, Deni Irawan, dan Bambang Priadi, atas peran sertanya dalam kegiatan penelitian ini. Kegiatan penelitian ini didanai dari DIPA BRPBATPP Bogor TA 2016.

\section{DAFTAR ACUAN}

Arifin, O.Z., Nugroho, E., \& Gustiano, R. (2007). Keragaman genetik populasi ikan nila (Oreochromis niloticus) dalam program seleksi berdasarkan RAPD. Berita Biologi, 8(6), 465-471.

Asih, S., Nugroho, E., Kristanto, A.H., \& Mulyasari. (2008). Penentuan variasi genetik ikan batak (Tor sorro) dari Sumatera Utara dan Jawa Barat dengan metode RAPD. Jurnal Riset Akuakultur, 3(1), 91-97.

Dunham, R.A. (2004). Aquaculture and fisheries biotechnology: Genetic approach. CABI Publishing. Cambridge USA, p. 85-99.

Falconer, D.S. (1989). Introduction to quantitative genetics. Edition 3. Longmans Green/John Wiley \& Sons, Harlow, Essex, UK/New York, 104 pp.

Gjedrem, T. \& Baranski, M. (2009). Selective breeding in aquaculture: An Introduction. Springer. Netherland, $221 \mathrm{pp}$.

Gusmiaty, M.R. \& Pongtuluran, I. (2012). Seleksi primer untuk analisis keragaman genetik jenis bitti (Vitex coffassus). Jurnal Perennial, 8(1), 25-29.

Indrawan, M. (2007). Biologi Konservasi. Jakarta: Yayasan Obor Indonesia, $15 \mathrm{hlm}$.

Kementerian Kelautan dan Perikanan [KKP]. (2006). Statistik perikanan budidaya Indonesia 2005. Direktorat Jenderal Perikanan Budidaya, Jakarta.

Kusmini, I.I., Gustiano, R., \& Mulyasari. (2011). Karakterisasi genetik ikan kelabau (Osteochilus kelabau) dari berbagai lokasi di Kalimantan Barat mengunakan metode RAPD (Random Amplified Polymorphism DNA). Berita Biologi, 10(4), 449-454.

Mulyasari, Soelistyowati, D.T., Kristanto, A.H., \& Kusmini, I.I. (2010). Karakteristik genetik enam populasi ikan nilem (Osteochilus hasselti) di Jawa Barat. Jurnal Riset Akuakultur, 5(2), 175-182.

Nei, M. \& Tajima, F. (1981). DNA polymorphism detectable by resctriction endonuclease. Genetics, 97 , 146-163.

Nugroho, E. (2011). Evaluasi variasi genetik ras-ras ikan gurame dengan menggunakan marker DNA.
Jurnal Perikanan (Journal of Fisheries Sciences), 13(2), 86-90.

Nugroho, E., Azrita, Syandri, H., \& Refilza. (2016). Evaluasi keragaman genetik ikan kalui (Osphronemus goramy) dari kabupaten Lima Puluh Kota, Sumatera Barat berdasarkan marka random amplified polymorphism DNA(RAPD). Jurnal Riset Akuakultur, 11 (4), 313-319.

Nugroho, E., Sukadi, F., \& Huwoyon, G.H. (2012). Beberapa jenis ikan lokal yang potensial untuk budidaya: Domestikasi, teknologi pembenihan, dan pengelolaan kesehatan lingkungan budidaya. Media Akuakultur, 7(1), 52-57.

Nugroho, E., Sundari, S., \& Jatnika. (2011). Variasi genetik hibrida ikan gurame dianalisis dengan menggunakan marker RAPD. Jurnal Riset Akuakultur, 6(1), 1-6.

Nurudin, F.A. (2013). Keanekaragaman jenis ikan di Sungai Sekonyer Taman Nasional Tanjung Puting. Kalimantan Tengah. Skripsi. Universitas Negeri Semarang, $99 \mathrm{hlm}$.

Parenrengi, A. (2006). RAPD fingerprinting of three species of grouper (Epinephelus spp.) from Makassar Strait, South Sulawesi, Indonesia. Indonesian Aquaculture Journal, 1(2), 105-119.

Parenrengi, A. \& Tenriulo, A. (2008). Genetic variability and population structure of grouper (Epinephelus suillus) from Makassar Strait and Bone Bay, South Sulawesi, Indonesian Aquaculture Journal, 3(2), 7787.

Parenrengi, A., Tenriulo, A., \& Ali, S.A. (2012). Genetic variability of three populations of flying fish, Hirundichthy oxycephalus from makassar strait. Indonesian Aquaculture Journal, 7(1), 1-10.

Putriana, I. (2011). Keragaman tiga populasi ikan tambakan (Helostoma temminkii) dengan metode RAPD (Random Amplified Polymorphic DNA) dan karakter morfometrik. Skripsi. Departemen Budidaya, Institut Pertanian Bogor. Bogor, $28 \mathrm{hlm}$.

Roslim, D.I., Hartana, A., \& Suharsono. (2004). Kemiripan genetika tiga populasi kelapa tipe dalam berdasarkan tiga metode analisis data penanda RAPD. Hayati, 10(1), 12-18.

Sharma, A., Namdeo, A.G., \& Mahadik, K.R. (2008). Molecular markers: new prospects in plant genome analysis. Pharmacognosy Reviews, 2(3), 23-31.

Simatupang, N.F. (2012). Karakterisasi ragam genetik ikan sepat (Trichogaster pectoralis) berdasarkan analisis RAPD (Random Amplified Polymorphic DNA) dan morfometrik. Skripsi. Departemen Budidaya, Institut Pertanian Bogor. Bogor, $23 \mathrm{hlm}$. 
Soewardi, K. (2007). Pengelolaan keragaman genetik sumber daya perikanan dan kelautan. Departemen Manajemen Sumberdaya Perairan, Fakultas Perikanan dan Ilmu Kelautan, Institut Pertanian Bogor. Bogor, $153 \mathrm{hlm}$.

Sundari, S., Iskandariah, Huwoyon, G.H., Kusmini, I.I., \& Gustiano, R. (2012). Keragaman genetik 3 populasi ikan tambakan (Helostoma temminckii) asal Sumatera, Jawa, dan Kalimantan menggunakan metode RAPD (Random Amplified Polymorphism DNA. Prosiding Indoaqua - Forum Inovasi Teknologi Akuakultur, hlm. 1109-1115.
Suryanto, D. (2003). Melihat keanekaragaman organisme melalui beberapa teknik genetika molekuler. USU digital library, $11 \mathrm{pp}$.

Tave, D. (1999). Inbreeding and Brood Stock Management. FAO Fish Technical Paper. No. 392. FAO. Rome, $122 \mathrm{pp}$.

Tingey, S.V., Rafalski, J.A., \& Hanafey, M.K. (1994). Genetic analysis with RAPD markers. In Coruzzi, C., \& Puidormenech, P. (Eds.). Plant Molecular Biology, 81, 491-500. 